
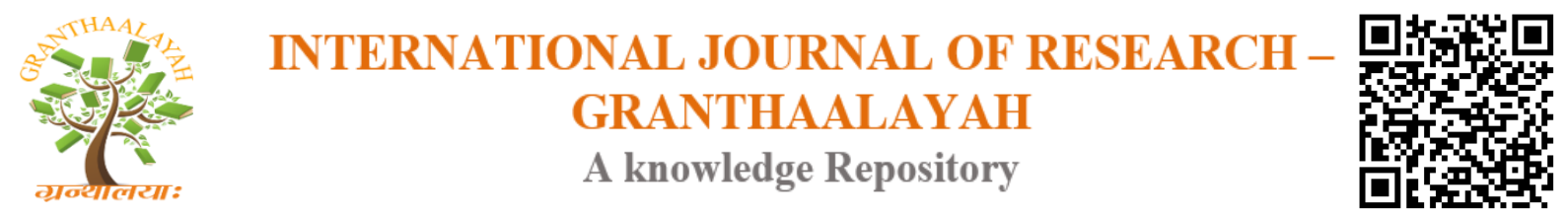

Social

\title{
A COMPARATIVE STUDY OF SOCIO ECONOMIC AND HEALTH STATUS OF SENIOR CITIZENS OF HIMACHAL PRADESH AND UTTAR PRADESH STATE
}

\author{
Kumar Ashwani *1 \\ ${ }^{* 1}$ Research Scholar, Sant Gadge Baba Amravati University, Amravati (M.S), India
}

\begin{abstract}
The main objective of the study was to compare the Socio Economic and Health Status of Senior Citizens of Himachal Pradesh and Uttar Pradesh State. 2000 sample were selected on the bases of simple random method viz: 1000 of each State. 500 male and 500 female gender wise categories were selected of each state. V. Kuupuswami scale (SES) and Barry TL Standardized Health Status Questionnaire (HSQ 12) was used for data collection. The percentage and contingency chi square method $\left(\mathrm{x}^{2}\right)$ were used for analysis of the data. The statistical analysis was found the significant difference in between socio-economic and health status of Himachal Pradesh and Uttar Pradesh State.
\end{abstract}

Keywords: Socio Economic Status (SES); Health Status; Senior Citizens of H.P. \& U.P. State.

Cite This Article: Kumar Ashwani. (2017). "A COMPARATIVE STUDY OF SOCIO ECONOMIC AND HEALTH STATUS OF SENIOR CITIZENS OF HIMACHAL PRADESH AND UTTAR PRADESH STATE." International Journal of Research Granthaalayah, 5(8:SE), 40-46. https://doi.org/10.29121/granthaalayah.v5.i8(SE).2017.2247.

\section{Introduction}

Himachal Pradesh is a captivating region of the Indian Himalayas. It is often referred to as the "Magical Showcase of Nature's Splendor" ideal for the travelers to travel, enjoy and relax. Abundant green grassland and wide valleys set against imposing snow-clad mountains; crystal clear lakes, flowing rivers and spurting streams; fruit laden groves and soft terraces of corn and tea are characteristics of Himachal Pradesh. It is the ultimate travel destination of India.

The state of Himachal Pradesh has boundaries with the Jammu and Kashmir in the North, Uttar Pradesh in the Southeast, Haryana in the South and Punjab in the West. It is located between 30"22' and 30"12' north latitude and between 75"47' and 79"4' east longitude. The mountainous state has altitudes ranging from 350 to 7000 meters (1050 ft. to $21000 \mathrm{ft}$.) above the sea level.

Uttar Pradesh is a state located in northern India. It was created on 1 April 1937 as the United Provinces, and was renamed Uttar Pradesh in 1950. Lucknow is the capital and Kanpur is the 
commercial capital and the largest city of Uttar Pradesh. On 9 November 2000, a new state, Uttarakhand, was carved from the mountainous Himalayan region of Uttar Pradesh.

Socio-Economic status (SES) is an economic and sociological combined total measure of a person's work experience and of an Individual's or family's economic and social position in relation to others, based on income, education, and occupation. When analyzing a family's SES, the household income, earners' education, and occupation are examined, as well as combined income, versus with an individual, when their own attributes are assessed.

Senior Citizen is a common euphemism for an elderly person in both UK and US, and it implies or means that the person is retired. This in turn usually implies or in fact means that the person is over the retirement age, which varies according to country.

Synonyms include pensioner in UK and retiree and senior in US. Some dictionaries describe widespread usage of "senior citizen" for people over the age of 65. "Senior citizen" is replacing the term old-age pensioner traditionally used in UK.

\section{Objective of the Study}

The following were the objectives of the study:-

1) To measure the Socio-economic Status of Senior Citizens living in Himachal Pradesh and Uttar Pradesh State.

2) To measure the Health Status of Senior Citizens living in Himachal Pradesh and Uttar Pradesh State.

\section{Hypothesis of the Study}

It was hypothesized that there will be significant difference in between Socio Economic and Health Status of Senior Citizens living in Himachal Pradesh and Uttar Pradesh State."

\section{Design of the Study}

The present researcher used simple random sampling method for the selection of 2000 subjects (Senior Citizens) for the present study. 100 Male and 100 Female Senior Citizens were taken together from each district taken for the present study of Himachal Pradesh and Uttar Pradesh State. For measuring the Socio-Economic Status of Senior Citizens of Himachal Pradesh and Uttar Pradesh State Kuppuswamy's Socio-Economic Standardized scale was used for the Investigation. Barry TL Standardized Health Status Questionnaire (HSQ 12) was used for measuring the Health Status of Senior Citizens living in Himachal Pradesh and Uttar Pradesh State, taken for the present study. 


\section{Statistical Analysis and Interpretations of the Data:}

Table 1: Table Showing the Area Wise Socio-economic Status (SES) of Senior Citizens of Uttar Pradesh and Himachal Pradesh

\begin{tabular}{|l|l|l|l|l|}
\hline \multirow{2}{*}{ SES } & \multicolumn{2}{l|}{ Rural } & Urban \\
\cline { 2 - 5 } & H. P. & U. P. & H. P. & U. P. \\
\hline Upper & $9(1.8)$ & $12(2.4)$ & $40(8)$ & $68(13.6)$ \\
\hline Middle & $30(6)$ & $71(14.2)$ & $72(14.4)$ & $124(24.8)$ \\
\hline Lower Middle & $189(37.8)$ & $196(39.2)$ & $204(40.8)$ & $184(36.8)$ \\
\hline Upper Lower & $145(29)$ & $131(26.2)$ & $109(21.8)$ & $94(18.8)$ \\
\hline Lower & $127(25.4)$ & $90(18)$ & $75(15)$ & $30(6)$ \\
\hline Total $(\mathrm{N})$ & $\mathrm{N}=500$ & $\mathrm{~N}=500$ & $\mathrm{~N}=500$ & $\mathrm{~N}=500$ \\
\hline Total Chi Square $\left(\boldsymbol{\chi}^{\mathbf{2}}\right)$ & 24.22 & & 42.84 & \\
\hline
\end{tabular}

Figure in parenthesis indicates the percentage: $\mathrm{df} .=4, \mathrm{tab} .=9.488$ at 0.05 level of significance

The above table no-I explores the socio economic status of the rural and urban areas citizen of Uttar Pradesh and Himachal Pradesh. The table clearly shows that lower middle class is the biggest class after upper lower class from number of frequencies point of view in rural and urban areas of H.P.( urban-40.8\% \& rural -37.8\%): and U.P. (rural-39.2 urban-36.8). Simply, it can be concluded that maximum senior citizens either rural or urban both have reported lower middle and upper middle socio-economic status.

Data explore an important finding that majority of urban senior citizens of Himachal Pradesh (77.6\% ) have lower middle, upper lower and lower class socio economic status while in Uttar Pradesh $65.8 \%$ urban reported in said categories, which shows that the population upper class people is more in urban areas of Uttar Pradesh.

Table also shows that upper class senior citizens of both states are mostly resides in urban areas, while the U.P. State is slightly ahead of H.P. from urbanization of senior residents. The calculated percentages for urban upper class in U.P. $13.6 \%$ \& H.P. $8 \%$ and urban middle class U.P. $24.8 \%$ \& H.P. $8 \%$ is also comparatively greater than rural areas senior citizens, as the calculated percentage for rural upper class U.P. $2.4 \%$ \& H.P.1.8\% and rural middle U.P. $14.2 \%$ \& H.P.6\%., which also concludes that percentages of senior citizens having healthy socioeconomic background is comparatively high in urban \& rural areas of U.P. state.

The above findings confirmed in chi square test, as the calculated chi square rural $=24.22$ and urban $=42.84$ is greater than that of tabulated value at 04 Degree of freedom and 0.05 level of significance. Employment is the major occupation of the Himachali people and majority of the people after getting employment preferred to settle their families in urban areas due to unavailability of IT resources, medical \& basic facilities and poor road connectivity in rural areas. Apart this, the rural areas of Uttar Pradesh is well enriched form basic facilities point of view with healthy road connectivity. The agriculture is also well irrigated and developed in U.P. 
while in H.P. the agriculture totally depends on monsoon. So like these, all components together playing vital role in gravitating the attitude of people towards urbanization. The same is depicted with the help of graph in Fig.

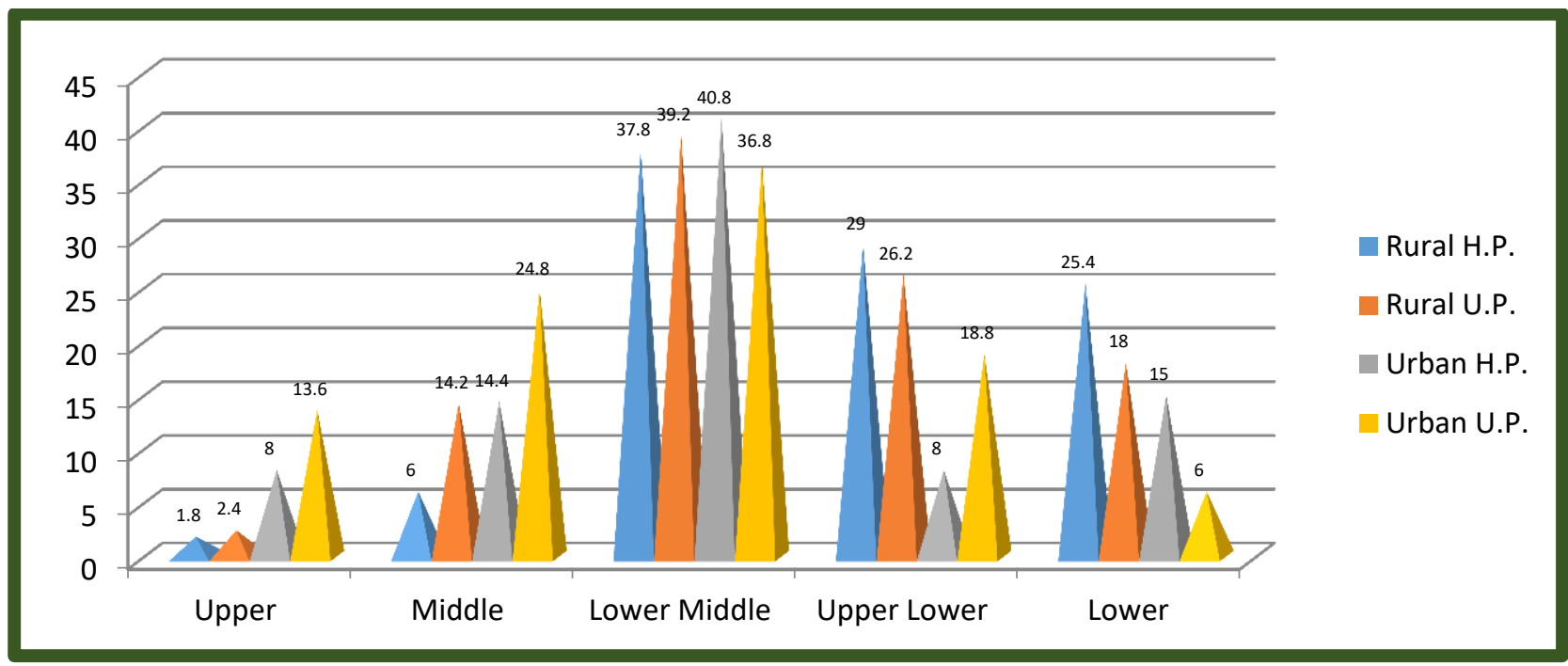

Graph 1: Showing the Socio-economic Status of Area Wise Senior Citizens of Himachal Pradesh and Uttar Pradesh State

Table 2: Showing the Gender Wise Health status of Senior Citizens of H.P. and U.P.

\begin{tabular}{|c|c|c|c|c|c|c|c|c|c|}
\hline \multirow{2}{*}{\multicolumn{2}{|c|}{ Health Items }} & \multicolumn{2}{|c|}{ Male } & \multicolumn{2}{|c|}{ Female } & \multicolumn{2}{|c|}{ (P) Male } & \multicolumn{2}{|c|}{ (P) Female } \\
\hline & & H.P. & U.P. & H.P. & U.P. & H.P. & U.P. & H.P. & U.P. \\
\hline \multirow{3}{*}{$\begin{array}{l}\text { (1) } \\
\text { Physical } \\
\text { function }\end{array}$} & Good & 226 & 198 & 254 & 171 & 45.2 & 39.6 & 50.8 & 34.2 \\
\hline & Average & 228 & 230 & 226 & 239 & 45.6 & 46 & 45.2 & 47.8 \\
\hline & Poor & 46 & 72 & 20 & 90 & 9.2 & 14.4 & 4 & 18 \\
\hline \multicolumn{2}{|c|}{ Chi Square $\left(\chi^{2}\right)$} & \multicolumn{2}{|c|}{7.587} & \multicolumn{2}{|c|}{61.12} & \multicolumn{4}{|c|}{ tab. value $=\mathbf{5 . 9 9 1}$} \\
\hline \multirow{3}{*}{$\begin{array}{l}\text { (2) } \\
\text { Bodily Pain }\end{array}$} & Good & 225 & 271 & 268 & 257 & 45 & 54.2 & 53.6 & 51.4 \\
\hline & Average & 211 & 156 & 194 & 190 & 42.2 & 31.2 & 38.8 & 38 \\
\hline & Poor & 64 & 73 & 38 & 53 & 12.8 & 12.8 & 7.6 & 10.6 \\
\hline \multicolumn{2}{|c|}{ Chi Square $\left(\chi^{2}\right)$} & \multicolumn{2}{|l|}{13.1} & \multicolumn{2}{|c|}{2.745} & \multicolumn{4}{|l|}{$\mathrm{Df}=2$} \\
\hline \multirow{3}{*}{$\begin{array}{l}\text { (3) } \\
\text { Health } \\
\text { Perception }\end{array}$} & Good & 260 & 169 & 224 & 169 & 52 & 33.8 & 44.8 & 33.8 \\
\hline & Average & 214 & 255 & 251 & 244 & 42.8 & 51 & 50.2 & 48.8 \\
\hline & Poor & 26 & 76 & 25 & 87 & 5.2 & 15.2 & 5 & 17.4 \\
\hline \multicolumn{2}{|c|}{ Chi Square $\left(\chi^{2}\right)$} & \multicolumn{2}{|l|}{47.4} & \multicolumn{2}{|c|}{42.12} & \multicolumn{4}{|c|}{$\mathrm{Df}=2$} \\
\hline \multirow{3}{*}{$\begin{array}{l}\text { (4) } \\
\text { Fatigue }\end{array}$} & Good & 269 & 284 & 305 & 321 & 53.8 & 56.8 & 61 & 64.2 \\
\hline & Average & 162 & 166 & 132 & 139 & 32.4 & 33.2 & 26.4 & 27.8 \\
\hline & Poor & 69 & 50 & 63 & 40 & 13.8 & 10 & 12.6 & 8 \\
\hline \multicolumn{2}{|c|}{ Chi Square $\left(\chi^{2}\right)$} & \multicolumn{2}{|c|}{3.874} & \multicolumn{2}{|c|}{5.726} & \multicolumn{3}{|l|}{$\mathrm{Df}=2$} & 991 \\
\hline \multirow{3}{*}{$\begin{array}{l}(5) \\
\text { Social } \\
\text { Function }\end{array}$} & Good & 278 & 254 & 270 & 285 & 55.6 & 50.8 & 54 & 57 \\
\hline & Average & 189 & 178 & 175 & 186 & 37.8 & 35.6 & 35 & 37.2 \\
\hline & Poor & 33 & 68 & \multirow{2}{*}{\multicolumn{2}{|c|}{$\begin{array}{r}129 \\
8.788\end{array}$}} & & 13.6 & 11 & 5.8 \\
\hline \multicolumn{2}{|c|}{ Chi Square $\left(\chi^{2}\right)$} & \multicolumn{2}{|c|}{13.541} & & & \multicolumn{2}{|c|}{$\mathrm{Df}=2$} & value & 91 \\
\hline
\end{tabular}


DOI: 10.5281/zenodo.887630

\begin{tabular}{|c|c|c|c|c|c|c|c|c|c|}
\hline \multirow{3}{*}{$\begin{array}{l}\text { (6) } \\
\text { Mental } \\
\text { Health }\end{array}$} & Good & 285 & 250 & 299 & 272 & 57 & 50 & 59.8 & 54.4 \\
\hline & Average & 194 & 157 & 166 & 118 & 38.8 & 31.4 & 33.2 & 23.6 \\
\hline & Poor & 21 & 93 & 35 & 100 & 4.2 & 18.6 & 7 & 22 \\
\hline \multicolumn{2}{|c|}{ Chi Square $\left(\chi^{2}\right)$} & \multicolumn{2}{|c|}{51.663} & \multicolumn{2}{|c|}{48.182} & \multicolumn{4}{|l|}{$\mathrm{Df}=2$} \\
\hline \multirow{3}{*}{$\begin{array}{l}\text { Average } \\
\text { Frequencies }\end{array}$} & I & 257 & 238 & 270 & 248 & 51.4 & 47.6 & 54 & 49.6 \\
\hline & II & 200 & 190 & 191 & 186 & 40 & 38 & 38.2 & 37.2 \\
\hline & III & 43 & 72 & 39 & 66 & 8.6 & 14.4 & 7.8 & 13.2 \\
\hline$\left(\chi^{2}\right)$ & \multicolumn{3}{|l|}{8.298} & \multicolumn{2}{|c|}{7.943} & \multicolumn{4}{|c|}{$\mathrm{Df}=2 \quad$ tab. value $=\mathbf{5 . 9 9 1}$} \\
\hline
\end{tabular}

Figure in parenthesis indicates the percentage: $\mathrm{df} .=2$, tab. $=5.991$ at 0.05 level of significance

The table no- 2 explores the components wise health status of the male and female senior citizens of Himachal Pradesh and Uttar Pradesh. While arranging the average percentages in descending serial order, it has been found that female of H.P. has been scored high in each components of health. The average percentage concludes that 54\% H.P. female were not only found good in health than female senior citizens of Utter Pradesh (49.6\%) but also reported better health than Male of Himachal Pradesh and Uttar Pradesh state respectively. The H.P. male (51.4\%) were found slightly ahead in health than male senior citizen of Uttar Pradesh (47.6\%) respectively.

The table also suggests that averagely around 39\% males and 37.5\% females of both states showed average health. Near about 14\% male and 13.2\% female of Utter Pradesh states reported poor health while the rate of poor health in Himachal is noted around $8.6 \%$ in male and $7.8 \%$ in female.

In over all conclusions we can say that the average rate of poor health in both genders is less than 13.6\% and $8.2 \%$ in Uttar Pradesh and Himachal Pradesh respectively, which shows that male and female senior citizens of both states in huge majority has reported healthier health status. During health components wise analysis, it has been found that male of Himachal Pradesh were found better in good health than male senior citizens of Uttar Pradesh in social functioning (H.P.55.6\% \&. U.P.50.8\%), health perception (H.P. 52\% \& U.P. 33.8\%), mental health (H.P. 57\% and U.P. 50\%) and Physical functioning (H.P. 45.2\% \& U.P. 39.6\%) respectively.

However, common health problems such as fatigue and bodily pain were found more in male and female of Uttar Pradesh. The 56.8\% \& 54.2\% male and 53.6\% \& 64.2\%, female of Uttar Pradesh reported severe body pain and feeling of fatigued most of the time in U.P., while in H.P. the same was $53.8 \%$ \& $45 \%$ in male and $51.4 \%$ \& $62.4 \%$ in female respectively.

The female of Himachal Pradesh were found comparatively much better than female of Uttar Pradesh in physical functioning (H.P.50.8\% U.P. 34.8\%) and health perception (H.P.44.8\% \& U.P.33.8\%) respectively, except social functioning (U.P. 57\% \& H.P. 54\%) and mental health (H.P. $61.2 \%$ \& U.P. 57\%).

The male and female of Uttar Pradesh and Himachal Pradesh differed significantly in respect to their physical functions, health perception, mental health and social functioning. The calculated value of female (physical function 61.12, mental health 48.183, health perception 42.14 and 
social functioning 8.788 and male mental health 51.66 , health perception 47.4 , social functioning 13.541 and physical function 7.59 is found significant at 0.05 level of significance.

In common aging health problems, the female of both states were found significantly differed in fatigue, while Male were found differed in Bodily pain. The calculated chi square of female fatigue is 42.12 and male body pain is 13.1 which are found greater than the tabulated value, which shows that the difference is significant.

Insignificant difference recorded in bodily pain and mental health's of female while male were found insignificant in mental health. The calculated chi square female (mental health 3.687 and bodily pain 2.745 ) and male (fatigue 3.874 ) is found insignificant at 0.05 level of significance, which meant that female of both states were found almost similar in mental health bodily pain , while male were found common in ageing problem i.e. fatigue.

However, the component wise calculated percentage shows that female and male of Himachal Pradesh both were found slightly better in maximum health components than the female and male of Uttar Pradesh.

The state wise comparison of health status of male and female senior citizens also done by employing chi square test on observed average frequencies and it was found that the calculated chi square male 8.298 and female 7.943 is significant at 0.05 level of significance, which meant that male and female of both states differed significantly in respect to their Health status.

The geographical and climate conditions of Himachal Pradesh have been rated excellent throughout the country for nurturing good health. The poor road connectivity in hilly area has its importance from physical activity point of view. Every day Himachali people have to perform near about 4 K.M. to 6 K.M. walking distance for their day to day business. The same is depicted with the help of graph in Fig.

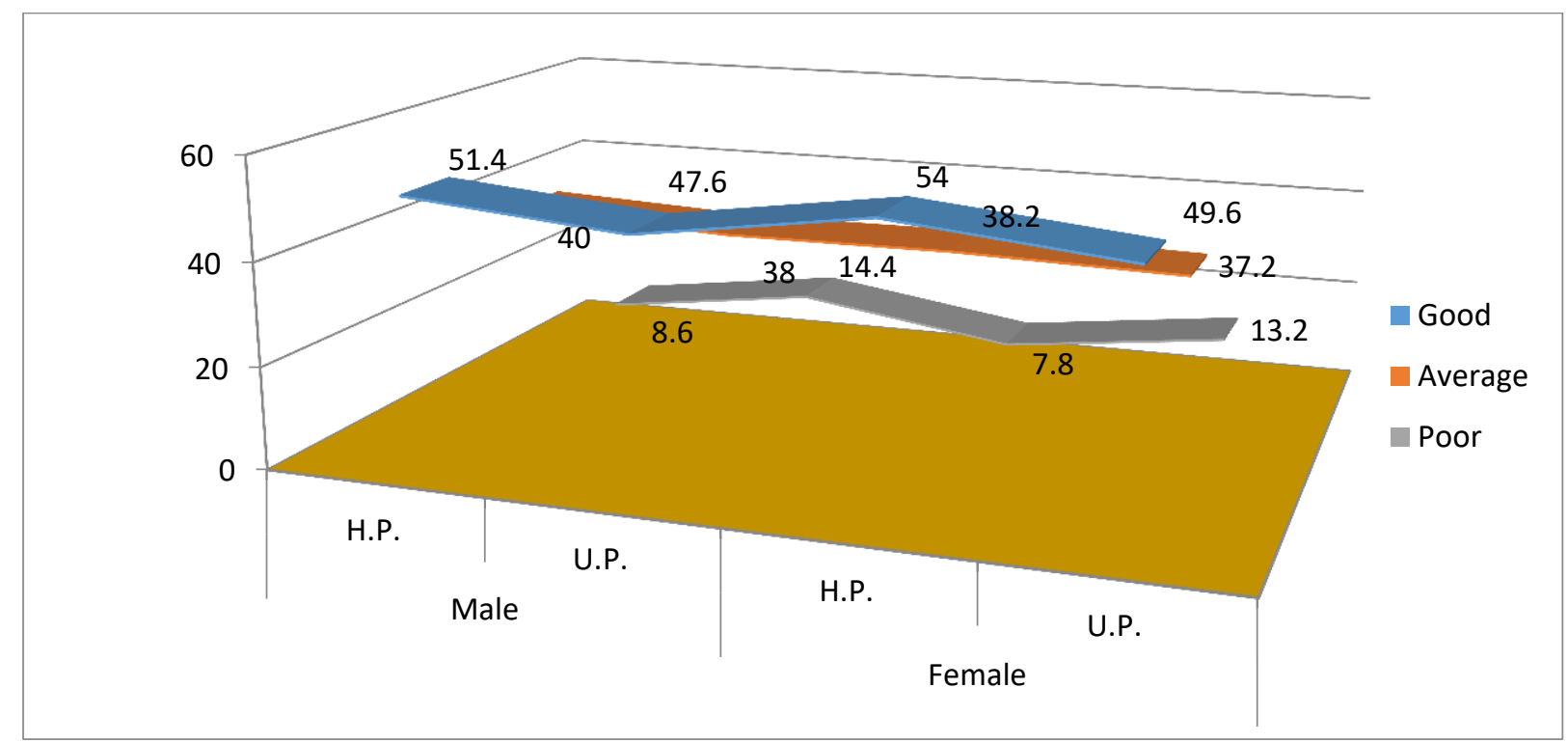

Graph 2: Showing the Gender Wise Health Status of Himachal Pradesh and Uttar Pradesh Senior Citizens 


\section{Conclusions}

The overall findings suggest that senior citizens of Himachal Pradesh were found poor in socioeconomic status than Uttar Pradesh, but Himachali were found better in Health status. Apart this, the findings also lead to following conclusions:-

- The rural and urban senior citizens of both states were differed significantly in respect to their socio economic status, while urban have reported comparatively better Socioeconomic status than rural.

- The male and female senior citizens of Himachal Pradesh and Uttar Pradesh state differed significantly in respect to their Health Status, but the senior citizens (male \& female) of Himachal Pradesh reported healthier health than Uttar Pradesh counterparts.

\section{References}

[1] Anshul Tiwari: "The Old Age Crisis in India" Youth Ki Awaaz, Jul- 17, 2009.

[2] G. B. Glies: Marketing, (London: Macdonald \& Evans Ltd., 2nd Ed., 1974.

[3] G. R. Rathod: Measuring the Socioeconomic Status of Urban below Poverty Line Families in Imphal City, Manipur: A Livelihoods Study” International Journal of Marketing, Vol: 1, Issue: $12,2012$.

[4] Golden, S. A. R. (2011). An Analysis Of Mental Stress In Heavy Alloy Penetrator Project, Tiruchirappalli. SELP Journal of Social Science, 13.

[5] http.www.wikipedia/himachal.com

[6] https://www. wikipedia.org/wiki/Senior_Citizen.

[7] https://www.wikipedia.org/wiki/Uttar_Pradesh.

[8] Regi, S. B., Golden, S. A. R., \& Franco, C. E. (2014). Self Employment As Sustainable Employment"-A Study On Self Employed Women's Association (Sewa) Gujarat, India. Indian Streams Research Journal, 4 (2), 1, 5.

[9] S. G. Vidhale: "A Study of Socio-economic Status, Scholastic Standard and its Relationship with Physical Fitness among Physical Education College Students" Vayam-Vidnyan, Amravati, Vol: 41, No-2, 2008. 